\title{
National Culture and Risk-Taking: Evidence from the Insurance Industry
}

\author{
CHRYSOVALANTIS GAGANIS $^{\mathrm{a}}$, IFTEKHAR HASAN ${ }^{\mathrm{b}, \mathrm{c}}$, PANAGIOTA PAPADIMITRI ${ }^{\mathrm{d}}$, and \\ MENELAOS TASIOU ${ }^{d}$ \\ a Department of Economics, University of Crete, Rethymno, Greece \\ ${ }^{\mathrm{b}}$ Gabelli School of Business, Fordham University, NY, USA \\ ${ }^{\mathrm{c}}$ Bank of Finland, Helsinki, Finland \\ ${ }^{d}$ Portsmouth Business School, University of Portsmouth, Portsmouth, UK
}

\begin{abstract}
The gravity of insurance within the financial sector is constantly increasing. Reasonably, after the events of the recent financial turmoil, the domain of research that examines the factors driving the risk-taking of this industry has been signified. The purpose of the present study is to investigate the interplay between national culture and risk of insurance firms. We quantify the cultural overtones, measuring national culture considering the dimensions outlined by the Hofstede model and risk-taking using the 'Z-score'. In a sample consisting of 801 life and non-life insurance firms operating across 42 countries over the period 20072016, we find a strong and significant relationship among insurance firms' risk-taking and cultural characteristics, such as individualism, uncertainty avoidance and power distance. Results remain robust to a variety of firm and country-specific controls, alternative measures of risk, sample specifications and tests designed to alleviate endogeneity.
\end{abstract}

Keywords: Insurance $\cdot$ Risk-taking $\cdot$ National Culture

JEL Classification: G22 - G32 - N20 - M14.

\Iftekhar Hasan

ihasan@fordham.edu

Chrysovalantis Gaganis

c.gaganis@uoc.gr

Panagiota Papadimitri

panagiota.papadimitri@myport.ac.uk

Menelaos Tasiou

menelaos.tasiou@port.ac.uk 
"Differences in the way distinct countries subjectively value insurance products have not come into being by chance. Patterns of appreciation are part of the culture of a society."

-- Geert Hofstede (1995, p.423)

\section{Introduction}

Insurance is fast becoming an imperative element of the financial sector that significantly contributes to economic growth (Haiss and Sümegi, 2008). Understandably, this also makes it a significant vulnerability of the financial system that could potentially derail it, eventually leading to a negative impact on the whole economy (Das et al., 2003; Harrington, 2009). Admittedly, this justifies policy-makers' motives to reform the regulatory framework of this industry (Gaganis et al., 2015), further promoting confidence in its soundness (Cummins et al., 2017).

Investigating the risk-taking of this domain is of paramount importance, especially as to what the unravelled global financial crisis revealed (Tarashev et al., 2009). Consequently, a number of studies delve into the factors driving the risk of insurers, shedding ample light in many respects. The plethora of existing studies focuses on firm-specific determinants (see Chen and Wong, 2004, pp.470-473, for a detailed review). Turning to the macro-level strand of literature that our study is addressed at, we find a limited number of prior studies. These consider country-specific characteristics, such as the the quality of institutions (Fields et al., 2012), regulations (Pasiouras and Gaganis, 2013) and competition (Cummins et al., 2017) as drivers of the industry's risk-taking. Arguably, these studies are greatly informative, yet far from being exhaustive.

In particular, we find informal institutions, such as national culture -that has made its way through the literature over the past three decades (Kirkman et al., 2006)- to be missing from the above explanatory list. Interestingly, anecdotal evidence and prior studies in the literature identify culture as a main determinant of financial institutions' stability. More specifically, a thought-provoking survey conducted by PricewaterhouseCoopers and The Economist's Intelligence Unit among financial services professionals in May 2008 reveals that $73 \%$ of the respondents identified "culture and excessive-risk taking" as the main drivers of the global financial crisis (PricewaterhouseCoopers, 2008).

From an empirical point of view, the interplay between these two drivers is well-documented, with national culture having been linked to the propensity of firms to invest in longer-term riskier projects (Shao et al., 2013), to the degree of individuals' financial risk-taking and purchase of stocks (Breuer et al., 2014) and the overall increased risk-taking trajectory of firms (Kreiser et al., 2010; Mihet, 2013; Li et al., 2013) and banks (Kanagaretnam et al., 2011; 2014; Ashraf et al., 2016; Ashraf and Arshad, 2017; Mourouzidou et al., 2017). Notwithstanding the volume of documented evidence, to this date there is no study examining this interplay from the viewpoint of insurance firms. Still, we believe that culture can be linked to the risk-taking 
trajectory of insurers for three main reasons that we abridge forthwith.

The first is based on abstract grounds and concerns the effect of culture on risk-taking of entities aside of industry. More specifically, it is seemingly well-documented by the abovementioned studies that the risk-taking of firms or financial institutions can be attributed to cultural effects making their way through managerial appetites for risk-taking. While this interplay from the viewpoint of insurers has not been examined, they belong to the group of financial institutions, in which, recent years have witnessed the lines separating insurers, banks and other financial firms rapidly getting thinner (Baluch et al., 2011). Therefore, one may expect similar cultural overtones when it comes to the risk-taking trajectory of this industry respectively.

The second reason insurers' risk-taking could be linked to culture is due to their clientele and regards the concept of 'moral hazard' (see e.g. Shavell, 1979; Stiglitz, 1983). This is a specific issue of paramount importance to insurers, according to which a customer may start behaving differently once insured. The reason is that this customer has less incentives to act similar to the pre-insured period, as coverage will be provided in exchange for a premium, the level of which is very difficult to accurately set due to asymmetric information. Of course, if we accept here that our values are culturally-dependent (see e.g. Hofstede, 1980) and as such turn out to impact our behaviour through our attitudes (see e.g. 'value-attitude-behaviour' hierarchy by Homer and Kahle, 1988); then, how we act under different situations (including that one assumed in the moral hazard concept) can be partially explained by culture. Extending the latter argument, the cost of risk that insurers face -stemming from not being able to correctly price their products and/or make correct provisions, and thus manage their assets accordingly- can be attributed to the behaviour of customers, which is a function that, among other factors, includes national culture.

The third reason why culture is important for the risk-taking trajectory of insurance firms can be attributed to the very definition of insurance. In particular, insurance is an instrument that one obtains to hedge a type of risk. Hofstede (1995, p.423) argues that this is exactly what makes insurance an inherently "culture-sensitive" product, as it offers a feeling of 'safety' that is subjectively appreciated as part of a society's culture. This, however, may imply that patterns of insurance consumption could be attributed to cultural differences, which is empirically proven by Chui and Kwok (2008). Reasonably, if culture is a strong predictor of insurance consumption, this means that, combined with the argument we made previously about the customer influence, insurers' task to manage the risk of these assets becomes even more crucial. In other words, assuming insurance contracts are affected by culture both in terms of volume and of customer incentives to exercise them, insurers' risk management is a very complex function in which culture is worth examining.

To the best of our knowledge, the only study linking national culture and insurance this far is that of Chui and Kwok (2008), providing findings in the direction of culture impacting insurance consumption patterns at the macro level, leaving a crucial void at the micro-level 
unexplored. In this study, we fill this void by focusing on the interplay between national culture and insurance firms' risk-taking. In doing so, the novelty added to the extant literature is twofold. First, we contribute to the limited strand of literature that focuses on the macro determinants of insurers' risk. Second, we contribute to the broader strand of literature contemplating the influence that culture exerts on financial decision-making which, seemingly, has received little attention in spite of its importance (Karolyi, 2016).

To meet our research objective, we employ three cultural dimensions that have been directly associated to insurance by prior studies (see Hofstede, 1995; Chui and Kwok, 2008); these are: power distance, individualism, and uncertainty avoidance. As a proxy for risk, we use the accounting-based measure of distance to default, namely the ' $Z$-score'. Our sample consists of 801 life and non-life insurance firms operating across 42 countries over the period 2007-2016. Overall, results reveal a strong and significant link between national culture and insurance firms' risk-taking that holds even after controlling for a variety of firm and countryspecific attributes, alternative measures of risk, sample specifications and tests designed to alleviate endogeneity. We will postulate that this influence may be effective through a direct or an indirect channel. In the former, national culture exerts influence on insurance firms through the risk-appetite of managers; whereas in the latter influence is exerted through the behavioural patterns of the insurance firms' clientele.

The remaining of this paper is structured as follows. Section 2 provides a background discussion of the strands of literature and the nexus we address in this study and formulates the research hypotheses. Section 3 describes the sample, list of variables and methodology. Section 4 contemplates the obtained results, testing their validity by performing some robustness checks. Section 5 concludes the study and offers our thoughts on the future direction of research.

\section{Background and Hypotheses}

\subsection{The gravity of insurance}

The role of insurance in the economy extends beyond the public's perception of it as a risktransfer mechanism to diversify risk (Das et al., 2003). Its role within the financial sector constantly escalates while its significant contribution to GDP growth that is derived from their assets and investment increases at a rapid pace (Haiss and Sümegi, 2008). According to the latest yearbook on insurance statistics (OECD, 2017, p.65), insurance penetration in the OECD countries in 2015 ranged from $1.6 \%$ in Turkey to $36.5 \%$ in Luxembourg, with the OECD average standing at $8.8 \%$. Admittedly, the role of financial institutions in general starts becoming noteworthy when systemic risk rapidly increases (Tarashev et al., 2009). In the insurance arena in particular, there is a rather long list of such examples. Das et al. (2003, p.19) list numerous selected insurance companies that failed across 8 countries in the $90 \mathrm{~s}$. Yet, the case

of the insurance conglomerate, AIG, is a phenomenon most recently observed by the whole 
world, having widespread repercussions for the global economy (Harrington, 2009; Eling and Marek, 2014). Understandably, in such turbulent times there are calls for reforms of the regulatory framework (Gaganis et al., 2015), while research of the motives behind the risk-taking trajectory of institutions is signified.

Much of the extant literature focuses on firm-specific attributes ranging from key financial ratios (see Chen and Wong, 2004, pp.470-473, for an in-depth review) to corporate governance (Eling and Marek, 2014). A handful of studies focus on the determinants of risk at the macrolevel, which our paper is addressed at. More specifically, Fields et al. (2012) investigate the interplay between institutional characteristics and risk. In particular, in a sample of 513 publicly-traded insurers operating in 66 countries, they find that greater investor protection and contract enforceability and higher quality of government is associated with lower levels of risk. Pasiouras and Gaganis (2013) examine the financial health of 1,762 life and nonlife insurance companies operating in 46 countries over the period 2005-2007. They find that the power of the supervisory authorities and regulations as to the technical provisions and investments have a strong and significant impact upon insurers' risk. More recently, Cummins et al. (2017) analyse 10 EU life insurance markets over the period 1999-2011, observing an inverse relation between competition and the risk of solvency.

Admittedly, this strand of literature sheds light on micro and macro-level determinants of insurance firms' risk. Nonetheless, this list is far from exhaustive, especially when it comes to the latter strand. Moreover, given the association of informal institutions, such as national culture, with the risk-taking trajectory of other financial institutions, such as banks (Kanagaretnam et al., 2011; 2014; Ashraf et al., 2016; Ashraf and Arshad, 2017; Mourouzidou et al., 2017), and the direct association to insurance products in general (Hofstede, 1995) and their consumption at a macro level in particular (Chui and Kwok, 2008), we conjecture that informal institutions are crucial when it comes to the risk of insurance firms and we forthwith explain why.

\subsection{The cultural overtones for insurance}

There is a variety of frameworks of national culture in the literature, the most prominent being that of Hofstede (Kirkman et al., 2006). Hofstede, (1984, p.389) defines culture as the "collective programming of the mind that distinguishes the members of one category of people from those of another". His seminal work, Culture's Consequences (Hofstede, 1980), constitutes the central study enabling the measurement of national values. Reasonably, it initiated a 'snowball effect' leading to an ever-growing body of literature that examines how culture influences every aspect related to decision-making and beyond (see Kirman et al., 2006, for an in-depth review of the literature, and Karolyi, 2016, for a survey in finance).

Hofstede has long argued that managerial decisions are inevitably bound to be "culturallydependent" (Hofstede, 1983, p.88). From a psychological point of view, the relationship between values and decision-making has its roots in the 'value-attitude-behaviour hierarchy', empiri- 
cally demonstrated by Homer and Kahle (1988). According to this theory, our values affect our attitudes that in turn affect our behaviour. Interestingly, Weber and Hsee (1998) note that values may in fact impact our behaviour, as to risk preference in particular, due to cultural differences in the way we perceive risk. Admittedly, this raises questions as to whether and how our shared values may be directly or indirectly related to the degree that societies unwittingly generate 'risk-seeking' firms, signifying this line of research from the viewpoints of both a more effective policy-making and an improved corporate governance (Mihet, 2013). Such questions have been partly answered by prior studies through the use of cultural dimensions developed by Hofstede (1980), exploring whether differences between countries as to the crucial cultural values such as individualism, uncertainty avoidance and power distance impact the risk-taking trajectory of firms (Kreiser et al., 2010; Mihet, 2013; Li et al., 2013) and financial institutions, such as banks (Kanagaretnam et al., 2011; 2014; Ashraf et al., 2016; Ashraf and Arshad, 2017; Mourouzidou et al., 2017). We conceptualise these cultural values below, linking them forthwith to our research hypotheses.

\subsubsection{The effect of individualism}

In the Hofstede model (Hofstede, 2001), cultures scoring high on individualism give priority to individual achievements. People in individualistic societies are more self-oriented and autonomous, mainly focusing on themselves and immediate relatives. On the contrary, low scores in this dimension reveal societies that aspire to collectivism, prioritizing the 'we' versus the 'I'. People in these societies emphasize in more collective achievements, prioritizing cohesion over individual needs.

Prior studies link individualism to overconfidence and overoptimism (Chui et al., 2010), which in turn is positively associated with individuals' financial risk-taking (Breuer et al., 2014) and underestimation of risks (Van den Steen, 2004). This may be pertinent to consider for both managers and customers of insurance firms, as both may express individualistic traits that could directly or indirectly increase the risk-taking trajectory of the insurer. More specifically, from the viewpoint of managers, Li et al. (2013) postulate that individualism is in line with a firm's practice of inducing equity-based managerial compensation which is associated with greater managerial risk-taking (Rajgopal and Shevlin, 2002; Low, 2009; Milidonis and Stathopoulos, 2011). Moreover, Mourouzidou et al. (2017) conjecture that this influence of individualism extends to the whole environment of the firm that the manager caters for, with managers in individualistic societies increasing risk-taking to maximize shareholders' wealth.

From the viewpoint of insurance customers, individualism may be pertinent to the trajectory of insurance firms as to the concept of 'moral hazard'. In particular, a highly individualistc customer may consider the insurance agreement as a 'risk-transfer' mechanism that leads to the fundamental conflict as stated by Stiglitz (1983, p.6): “[...] the more and better insurance that is provided against some contingency, the less incentive individuals have to avoid the insured event, because the less they bear the full consequences of their actions". This conflict is in 
line with the incentives of strongly individualistic societies. Moreover, in these societies, insurees' self-enhancement bias and their stringent preference of market-based insurance over the social network system have both been linked to higher insurance consumption (Chui and Kwok, 2008) that could potentially enforce the impact of the previous argument, as both the volume of contracts will be higher, and the propensity of customers to yield when the concept of moral hazard appears.

Collectively considering the above, we postulate that individualism will be positively related to insurers' risk, either through the risk appetite of managers or the firm's clientele.

H1. Individualism is positively associated with insurance firm risk.

\subsubsection{The effect of uncertainty avoidance}

Uncertainty avoidance shows the degree to which members in a society feel uncomfortable with uncertainty and ambiguity (Hofstede, 2001). Cultures with high scores in this dimension are hesitant about ambiguity around them, preferring clear rules of conduct and a more predictable environment. Kwok and Tadesse (2006) find that bank-based financial systems thrive in these cultures, as they provide a higher security on returns (e.g. deposit insurance) in contrast to equity-based systems that, while providing a higher rate of return, their daily fluctuations pose a serious source of uncertainty.

Overall, uncertainty avoidance is of utmost importance to firms in which information uncertainty is greater due to the inherent complexity in estimating and managing risk (Mihet, 2013). Undoubtedly, insurance firms are such examples, constantly trying to price their services in such a way that balances the risk and incentive effects under fierce concepts like 'moral hazard' (Stiglitz, 1983). From the viewpoint of managers, while CEOs are generally more risktolerant than the lay population; traits such as risk-aversion are naturally affecting corporate actions too (Graham et al., 2013). Of course, being uncertain-averse does not necessarily mean taking less risks, but potentially taking more calculated risks (Mihet, 2013). This is in line with the conjectures of $\mathrm{Li}$ et al (2013) that managers in risk-averse cultures tend to avoid innovative projects, or require a higher risk-premium for them.

Arguably, from the viewpoint of customers, those sharing traits of high uncertainty avoidance type could be seen to pose a lower level of risk for insurers. The reason is that individuals sharing such traits shun uncertainty and any form of risk in general. Therefore, the propensity to change their behaviour increasing the risk of exercising their contract after they sign it (i.e. in the concept of moral hazard) arguably remains low. In that sense, we postulate that insurers may predict the risk of customers more accurately, and as such price their contracts more efficiently, make better provisions and thus face less unpredicted risks, when their clientele shares traits of low uncertainty avoidance type.

Collectively considering the above, we conjecture that uncertainty avoidance will be negatively related to insurers' risk, either through the lower risk appetite of managers or the firms' 
uncertainty-averse clientele.

H2. Uncertainty avoidance is negatively associated with insurance firm risk.

\subsubsection{The effect of power distance}

Power distance shows the degree to which a society accepts inequality that stems from differences in physical and intellectual capacities (Hofstede, 2001). Cultures scoring high on this dimension accept more easily these inequalities, eventually forming a social stratification. Cultures with low scores on this dimension do not accept the status quo, challenging it in advancing their personal or in-group's interests.

Managers in such cultures are more eager to engage in risky behaviours in order to better their firm's standing (Shane, 1993). Consequently, according to Kreiser et al. (2010, p.963), these managers will be more willing to enact "risky offensive strategies", as opposed to managers in high power distance cultures that are more likely to adopt "fortify-and-defend" practices that solidify the firm's position in the industry. The authors also conjecture that organizations in such cultures tend to implement tight control mechanisms, in which individuals have considerably less autonomy to make "bold decisions" and as such the organizations will be associated with lower levels of risk. In complementing the latter, Hofstede (1984) argues that in low power distance cultures people are less likely to comply with their superiors, ultimately acting on their own, which, combined with the arguments that individuals in said cultures are more intent on bettering their position (Kreiser et al., 2010), means that it may well result in a relationship conflict within the firm. For instance, Frijns et al (2016, p.538) illustrate how such conflicts may arise within a firm, arguing that "in a low power distance society, people are often encouraged to share their alternative views. These differences suggest that directors may perceive the group dynamics of the board differently, which may result in relationship conflict". According to the authors, this dimension may in fact influence the directors' eagerness to share their opinions due to potentially induced relationship conflicts.

In an alternative, but complementary interpretation, Doney et al. (1998, p.613) argue that this dimension essentially addresses the "predominance of norms for conformity (doing what is accepted and proper)" [e.g. high power distance cultures] versus "independence (doing whatever one wants to do)" [e.g. low power distance cultures]. Clearly, and as the authors also postulate, the latter results in hampering the trust between two parties, e.g. a firm and its clientele, as to the former's ability to predict the latter's behaviour. On the other hand, high power distance cultures greatly regard predictability in relationships, which "paves the way for trust [e.g. among two parties] to form". Understandably, taking this to the situation where insurers and insured being two parties among which trust is a key element that potentially softens the issue of moral hazard, customers in high power distance cultures will be more trustful, conforming to the norms and be more predictable as to their behaviour post-contract.

Taking into consideration the above, we postulate that power distance will be negatively 
related to insurance firms' risk through conflicts and behaviours attributed to managers or insured individuals in such cultures.

H3. Power distance is negatively associated with insurance firm risk.

We have hereby conjectured that the considered dimensions of national culture may exert a negative (uncertainty avoidance, power distance) or positive (individualism) influence on insurers' risk-taking through the managers or the clientele's culture-specific traits. It is worth noting that a limitation of our study at this point is that, due to data unavailability regarding the behavioural concepts and preferences of both groups (i.e. risk appetite of managers and change in risk of customers after signing an insurance contract), we cannot prove such a causal relationship from these two channels. Thereby, similarly to past studies in the literature examining the impact of national culture on the risk-taking of firms (Kreiser et al., 2010; Mihet, 2013; Li et al., 2013) and banks (Kanagaretnam et al., 2011; 2014; Ashraf et al., 2016; Ashraf and Arshad, 2017; Mourouzidou et al., 2017), the channels through which culture flows impacting the risk trajectory of insurers will remain a conjecture while we quantify the overall effect these dimensions have upon the risk of insurers irrespective of the channel. That is, we measure the direct, overall effect of culture upon insurers' risk-taking.

\section{Sample, Variables and Methodology}

We obtain all firm-specific variables from the SNL Financial (S\&P Global Market Intelligence Platform). Our sample consists of 801 life and non-life insurance firms operating across 42 countries over the period $2007-2016^{1}$, structured in an unbalanced panel of 6,271 observations. We give further details the considered variables and the estimated model in the following subsections.

\subsection{Variables}

\subsubsection{Risk of insurance firms}

We measure the risk of insurance firms with the natural logarithm of the accounting-based measure of distance to default, namely the 'Z-score' ${ }^{2}$ that is constructed as follows:

$$
\mathrm{Z}_{\text {-score }} i, t=\frac{\overline{R O A}_{i}+\overline{E A}_{i}}{\sigma_{R O A i}}
$$

\footnotetext{
${ }^{1}$ This database offers a broad cross-country coverage on insurance firms from 2005 onward, as data for the preceding years almost exclusively concern US firms. Furthermore, given that our dependent variable is constructed with a three-year rolling window period (see subsection 3.1.1 for more details), our final sample eventually starts from the year 2007.

${ }^{2}$ This is the main risk measure employed for our baseline results. For alternative proxies of risk see robustness analysis, section 4.2 .
} 
where $\overline{R O A}_{i}$ is the temporal mean of Return to Assets ( $R O A$ ) for firm $i, \overline{E A}_{i}$ is the temporal mean of Equity to Assets ratio $\left(E A\right.$ ) for firm $i$ and $\sigma_{R O A i}$ is the standard deviation of Return to Assets for firm $i$. All three above-mentioned components of this measure are computed within a three-year time rolling window to smooth the 'Z-score' values, avoiding them from being driven by sudden changes in $R O A$ or $E A$ (see Schaeck et al., 2011, p.212 for more details). This means that, for instance, the Z-score of the year 2007 is constructed taking into account the three-year time period 2005-2007.

This measure is frequently used in both the banking (see Boyd et al., 1993; Laeven and Levine, 2009; Houston et al., 2010), and the insurance literature (Shim, 2011; 2017; Pasiouras and Gaganis, 2013; Milidonis et al., 2017). Essentially, it shows the number of standard deviations below the mean that profits must decrease to completely deplete equity. Thereby, higher figures indicate lower risk of solvency and vice versa. 'Z-score' boasts some desirable properties, among which of particular importance for our case is that it is objective in measuring risk across different groups, such as life and non-life insurance (Pasiouras and Gaganis, 2013). We will hereby use its natural logarithm to control for non-linear effects and outliers, while we also trim the $1^{\text {st }}$ and $99^{\text {th }}$ percentiles to remove more persistent outliers that were found not having been treated by the use of the natural logarithm. Finally, to be consistent with the interpretation of this measure as risk, similarly to prior studies in the national culture strand of literature using this measure (e.g. Mihet, 2013; Kanagaretnam et al., 2014; Mourouzidou et al., 2017), we invert it multiplying eq(1) by minus one. Therefore, higher values of the dependent variable now indicate greater risk and vice-versa. We will henceforth refer to this measure as "Risk".

\subsubsection{National culture}

In section 2, we provided a background discussion of the variables that will be used as proxy for national culture, namely individualism, uncertainty avoidance and power distance (see subsections 2.2.1 to 2.2.3 accordingly). These are obtained by Hofstede (see Hofstede, 1980; 2001, for a detailed analysis of each dimension, their origin and method of construction), and they ultimately measure each dimension of culture according to the Hofstede framework on a $0-100$ scale. These dimensions have jointly or individually appeared in over 180 studies in top-tier business and psychological journals (see Kirkman et al., 2006, for a cross-discipline review, and Karolyi, 2016, for a survey in finance). According to Kirkman et al. (2006) there have been few critiques that these dimensions could be overly simplistic in collapsing individual attributes to a single dimension. Yet, as the author argues, their use in top-tier journals proves their broader acceptance among scholars in a variety of disciplines. As per the hypotheses H1 to H3 made in subsections 2.2.1 to 2.2.3 respectively, we expect a positive relationship between individualism and risk and a negative relationship among uncertainty avoidance/power distance and risk. 


\subsubsection{Control variables}

In the analysis of the link between national culture and risk-taking in the insurance industry, we control for various firm and country-specific characteristics. With respect to the former, following Pasiouras and Gaganis (2013), we control for the size, organizational form and business activity of the insurance firms that have been proved to be significant determinants when it comes to insurance firms' risk of solvency (Cummins et al., 1995; Adams, 1996; Adams et al., 2003). More specifically, we proxy size with the natural logarithm of total assets (hereafter referred to as 'SIZE'); organizational form with a dummy variable that takes the value of 1 if the firm is a stock insurer (i.e. publicly-traded, thus controlled by a group of shareholders) and 0 if it is a mutual insurer (hereafter referred to as 'STOCK'). We proxy the business activity of insurance firms with a dummy variable that takes the value of 1 if the insurer engages in long-term (i.e. life insurance) and 0 if the insurer engages in short-term (i.e. property/casualty insurance) business segments (hereafter referred to as 'LIFE'). This captures potential differences in actuarial principles, notice for changes in underwriting terms, adjustments for unanticipated losses, etc. (Pasiouras and Gaganis, 2013).

We include a variety of cross-country variables that capture several forms of heterogeneity, as to macroeconomic, insurance, institutions and finance-related aspects of the countries that the insurers operate in. These are individually and jointly included in the analysis (see section 4 for further details). Macroeconomic variables capture problems in the financial sector and monetary instability across the countries in our sample. More specifically, we include GDP growth (herafter reffered to as 'GDPGR'), as the likelihood of issues in the financial sector to arise is greater when GDP growth is low (Demirgüc-Kunt et al., 1998). Moreover, inflation rate (hereafter 'INFL') captures the monetary instability in a country, with higher values denoting countries that have underdeveloped financial systems and experience financial crises Demirgüc-Kunt et al., 1998). Following Pasiouras and Gaganis (2013), we use the ratio of insurance premium to GDP (hereafter 'PREM') as proxy for the overall development of the insurance industries across countries. In addition, we use the Herfindahl-Hirschman Index (HHI) to measure the degree of competition (see e.g. Boyd et al., 2006; De Nicoló and Loukoianova, 2007) among insurers across countries, which is defined as the sum of the squared market shares of each insurer in each country and year. Data for GDPGR and INFL stem from World Bank's national accounts data, PREM is obtained from the Global Financial Development Database (June 2017 version), while HHI is constructed elaborating on SNL Financial data. Next, we control for the overall quality of the institutions across countries in our sample. There is a rich discussion in the IAIS core principles (2003, p.7) regarding the need for " $a$ reliable, effective, efficient and fair legal and court system [...] whose decisions are enforceable". Pasiouras and Gaganis (2013, p.635) conjecture that "[...] in countries with low legal protection, corruption and overall poor quality of legal institutions, there may be higher opportunities for gambling and risk-taking”. The Worlwide Governance Indicators database is a great source in this respect, offering aggregate indicators of six broad dimensions of governance, namely Voice 
and Accountability, Political Stability, Government Effectiveness, Regulatory Quality, Rule of Law and Control of Corruption (for more information on the sources, methodology and analysis of each, see Kauffmann et al., 2010). We build an overall index of institutional development (hereafter 'INSTDEV') using the non-weighted arithmetic average of the six aforementioned dimensions of governance ${ }^{3}$. Although it is often conceptually criticised, it still remains the most frequent scheme to the construction of composite indicators in the absence of a theoretical framework or an expert's opinion to justify differential weighting (see Greco et al., 2018, for a review). Finally, we control for heterogeneity related to the stock markets across countries. More specifically, we use the ratio of stock market capitalization to GDP (hereafter 'CAP'), as large stock markets are more liquid thus offering the ability to mobilize capital and diversify risk (Demirgüç-Kunt and Levine, 1996), and stock price volatility (hereafter 'VOL'), excess values of which may cripple investment (De Long et al., 1989). We obtain both variables from the Global Financial Development Database (June 2017 version).

Table 1 contains summary statistics for all variables mentioned above. Table 2 reports the correlation coefficients among them.

[Insert Tables 1 and 2 Around Here]

\subsection{Methodology}

To explore the effect that national culture exerts on insurance firms' risk, while controlling for several firm and country-specific characteristics, we employ regressions of the following form:

$$
\operatorname{Risk}_{i, k, t}=\alpha+\beta_{1} \text { Firm }_{i, k, t}+\beta_{2} \text { Country }_{k, t}+\gamma \text { Culture }_{k}+\delta \text { Year }_{t}+\varepsilon_{i, k, t}
$$

where $i$ corresponds to insurance firm $i, k$ corresponds to country $k, t$ corresponds to year $t$. Risk $_{i, k, t}$ is the inverse of 'Z-score', for firm $i$, in country $k$ in year $t$. Turning to the explanatory variables, Firm $_{i, k, t}$ denotes firm-specific attributes for insurance firm $i$ in country $k$ in year $t$; Country $_{k, t}$ denotes country-specific attributes (see Panel B, Table 1) in country $k$ in year $t$, and

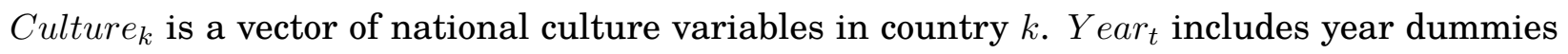
in time $t$, and $\varepsilon_{i, k, t}$ denotes residuals.

We estimate a static model instead of a dynamic one mainly due to the time-constant nature of the variables of interest (i.e. national culture). This is in accordance with similar studies (see e.g. Kanagaretnam et al., 2011; 2014) utilizing such static specifications to estimate their respective models. Yet, we believe that we capture a generous amount of heterogeneity across firms and countries as well as temporal heterogeneity across the panel -via the use of firm

\footnotetext{
${ }^{3}$ Due to very high correlation among the dimensions, it is not feasible to use them jointly in regression analysis. However, we do test them individually in additional (unreported) regressions, finding no significant difference sings and significance-wise as to both the key and control explanatory variables.
} 
and country-specific variables and year dummies respectively-, thus isolating these from inducing bias in the parameters of interest (i.e. coefficient $\gamma$ in eq.2). Furthermore, we correct for heteroskedasticity and serial dependence by estimating our model with robust standard errors clustered by firm (Petersen, 2009). We begin estimating (2) as a baseline model of only firm-specific variables and year dummies, adding one set of country-level variables (i.e. macroeconomic, insurance, institutional and stock market-related) at a time for each considered dimension of national culture (columns 1 to 5 in Tables 3, 4 and 5), eventually controlling jointly for all these attributes at the end (column 6 in Tables 3, 4 and 5). Considering the panel nature of our sample, we use a random effects model to fit these specifications, which is validated by the Breusch and Pagan Lagrange-multiplier test. Yet, we should note that the use of OLS did not alter the results by any means. We report all results in Tables 3,4 and 5 . We discuss them in the following section and we forthwith test their validity by performing some additional robustness checks.

\section{Results and Discussion}

\subsection{Base Results}

We regress a measure of risk (inverse of 'Z-score') on dimensions of national culture, controlling for various firm and country-specific attributes, the latter related to a spectrum ranging from macroeconomic to stock-market controls. We are ultimately interested in collectively controlling for all these attributes to isolate the effect of national culture as much as possible, yet, we also run and report regressions involving one set of attributes at a time. Tables 3,4 and 5 report all regressions of our baseline results. As discussed in the Methodology section, we make use of a random effects (RE) model to exploit the panel nature of our sample, the validity of which is confirmed by the Breusch and Pagan Lagrange-multiplier test. For space-saving reasons, where possible, we will restrict the discussion of results to the overall model (column (6) in Tables 3, 4 and 5) ${ }^{4}$.

\section{[Insert Tables 3,4 and 5 Around Here]}

Consistent with our first hypothesis, individualism appears to be positively associated to insurance firms' risk. This conjecture is statistically validated for all specifications (Columns (1) to (6) in Table 3). In particular, by collectively controlling for all considered attributes, individualism is positively associated with insurance firm risk at the $1 \%$ level of significance $\left(\gamma_{\text {IDV }}=0.00227, p<0.01\right.$, see Table 3, column (6)). Therefore, the higher a country scores in this cultural dimension, the worse the implications for the insurance firms operating in this

\footnotetext{
${ }^{4}$ In an alternative specification, we split our sample in life and non-life insurance firms on the basis of culture influencing their risk levels in different manners. In performing the above set of regressions separately (unreported for brevity) we find no significant difference among the two.
} 
country. This is in line with previous studies negatively associating individualism to the risktaking trajectory of SMEs (Kreiser et al., 2010), firms (Mihet, 2013; Li et al., 2013) and banks (Kanagaretnam et al., 2011; 2014; Ashraf et al., 2016; Ashraf and Arshad, 2017; Mourouzidou et al., 2017). Delving into quantifying the effect of individualism, after controlling for macro, insurance, institutional and stock market characteristics, insurance firms operating in a country that on this cultural dimension scores one standard deviation $\left(\sigma_{I D V}=24.06\right)$ higher than the average country's score $\left(\mu_{I D V}=64.73\right)$ are expected to be, on average, roughly $5.46 \%$ more risky $\left(\gamma_{I D V} \times \sigma_{I D V}\right)$, all other things held constant.

Moving to the second cultural dimension, uncertainty avoidance -as expected according to our second hypothesis- is negatively associated with insurance firms' risk. In testing this hypothesis, we find strong evidence of this relationship across all specifications (columns (1) to (6) in Table 4) of our baseline results at the $1 \%$ level of significance. This implies that higher scores in this cultural dimension indicate lower levels of risk for the insurance firms operating in this country. Prior studies in the domains of SMEs (Kreiser et al., 2010), firms (ihet, 2013; Li et al., 2013) and banks (Kanagaretnam et al., 2011; 2014; Ashraf et al., 2016; Ashraf and Arshad, 2017; Mourouzidou et al., 2017) confirm this inverse relationship between uncertainty avoidance and risk-taking. Turning to the economic impact this relationship entails in our sample $\left(\gamma_{U A I}=-0.00424, p<0.01\right.$, see Table 4, column (6)), having controlled for various firm and country-specific attributes, insurance firms operating in a country that scores one standard deviation $\left(\sigma_{U A I}=21.381\right)$ higher than the average uncertainty averse country $\left(\mu_{U A I}=57.352\right)$ are expected to be, on average, 9.07\% less risky $\left(\gamma_{U A I} \times \sigma_{U A I}\right)$, all other things equal.

Finally, we find an inverse relationship between the power distance index and insurance firms' risk that is statistically verified in five out of the six specifications of our base results (i.e. apart from 'Stock Market' specification, column (5) of Table 5). Considering our overall model (column (6) in Table 5), this cultural dimension is inversely related to insurers' risk at the $1 \%$ level of significance $\left(\gamma_{P D I}=-0.00375, p<0.01\right)$, implying that countries scoring high in this dimension are expected to be on average less risky. This relationship has been also verified by prior studies in the domains of SMEs (Kreiser et al., 2010), firms (Mihet, 2013) and banks (Ashraf et al., 2016; Ashraf and Arshad, 2017; Mourouzidou et al., 2017). Particularly for our sample, and having controlled for and holding other attributes constant, insurance firms operating in a country that is one standard deviation $\left(\sigma_{P D I}=19.859\right)$ higher than the average country's score $\left(\mu_{P D I}=49.012\right)$ of this dimension are expected to be roughly $7.45 \%$ less risky.

Overall, we find that cultural dimensions indeed affect the risk-taking of insurance firms. Consistent with our hypotheses and prior studies in the literature, we find positive cultural overtones as to the dimensions of uncertainty avoidance and power distance, and negative cultural overtones as to the dimension of individualism. 


\subsection{Robustness checks}

We test the sensitivity of the obtained results in three distinct ways. First, we estimate the Model of eq.(2) regressing alternative measures of risk. More specifically, following prior studies (Lepetit et al., 2008; Barry et al., 2011; and more recently, Doumpos et al., 2015) we disaggregate the dependent variable (inverse of 'Z-score') into its two main ratio components: $\mathrm{ZPR}_{i, t}=\frac{R O A_{i}}{\sigma_{R O A_{i}}}$ and $\mathrm{ZLR}_{i, t}=\frac{E A_{i}}{\sigma_{R O A_{i}}}$. The former, $Z P R$, multiplied by minus one, exhibits the portfolio risk of an insurance firm, while the latter, $Z L R$, also multiplied by minus one, indicates leverage risk. We find no change in the dynamics between the key variables of interest and insurance firm risk, with all parameters of interest exhibiting the expected sign and statistical significance at the $1 \%$ level for all cultural variables. These results are reported in specifications (1) and (2) of Table 6 for each cultural dimension accordingly. Moreover, we have also used the standard deviation of ROA $\left(\sigma_{R O A}\right)$ for a three-year rolling window period (unreported) as an alternative proxy of risk, finding no differences whatsoever.

A second way we test the validity of our results is to see whether the observed effects are attributed to turbulent periods, such as the recent global financial crisis. Insurance traditionally poses less systemic risk than banks, though recent years have seen the distinction between these two types of financial institutions getting thinner, forming ever-closer ties that are often abbreviated to "bancassurance" (Baluch et al., 2011, p.126). While we limit the bias of our parameters of interest (i.e. $\gamma_{I D V}, \gamma_{P D I}, \gamma_{U A I}$ ) as to the timely factors by accounting for temporal heterogeneity (e.g. adding year dummies in the estimation of our model of interest), admittedly, the recent financial turmoil had significant repercussions echoed throughout the financial systems around the globe. Thus, from a sensitivity perspective, it is interesting to validate whether excluding this turbulent period from our sample may alter the results. More specifically, we re-estimate our overall model excluding this time the period around the global financial crisis (e.g. years 2007 to 2009) ${ }^{5}$. We report these results in specification (3) of Table 6 for each cultural dimension accordingly. We find no evidence contradicting our baseline results, with the parameters of interest, i.e. $\gamma_{\mathrm{IDV}}, \gamma_{\mathrm{UAI}}$ and $\gamma_{\mathrm{PDI}}$, being significant at the 5\%, $1 \%$ and $1 \%$ levels accordingly.

Last but not least, we address the issue of endogeneity of culture by employing an instrumental variable (IV) approach to isolate its exogenous component. Our concerns about endogeneity are linked to three common sources: reverse causality, omitted variable bias and measurement error.

In regard to the first, it is important to recall that the main purpose of our study is to examine the impact of national culture on the risk-taking behaviour of insurers. However, one could argue that the causal effect arises via the opposite route, hence the issue of reverse causality. We argue that this is highly unlikely as a generally accepted notion is that a nation's cultural norms evolve very slowly over large periods of time (Williamson, 2000; Hofstede et al.

\footnotetext{
${ }^{5}$ Due to the nature of our dependent variable, i.e. constructed in a three-year rolling window, we also exclude years 2010 and 2011 that contain the GFC period as well.
} 
2010) as opposed to the risk element that is much more volatile over time. Thus, it is less likely that it is the insurance sector's risk to be driving national culture.

When it comes to omitted variable bias and measurement error, our primary concern could be that the impact of national culture on bank risk could be driven by other factors that have not been considered or are unobservable. Although we consider a range of country and firmlevel characteristics throughout our main analysis, there may be a possibility that some elements are not taken into account. Moreover, measurement error of our explanatory variables of interest could potentially further influence our results. For these reasons, we perform the IV analysis abbreviated forthwith (see Appendix B for more details) accounting, up to some extent, for such concerns.

The fundamental prerequisite of an IV analysis is the choice of proper instrumental variables from both a conceptual and a methodological perspective. Particularly, instruments need to be selected carefully in that they intrinsically relate (both concept and correlation-wise) to the first stage dependent variable (i.e. culture), but not with the residuals of the second stage regression. We hereby select factors inherently related to culture, such as religion, geography and language (see e.g. Hofstede, 2001). Following prior studies (e.g. Kwok and Tadesse, 2006; Li et al., 2013; Mourouzidou et al., 2017; Boubakri et al., 2017), we proxy geography with world region dummies that a country belongs to (see Appendix B for more details), we proxy religion with the population's fraction in each of the three most spread religion faiths (i.e. Roman Catholic, Protestant, Muslim) and language with the fraction of the population speaking the official language. With respect to the specification and validity of the instruments, as expected following their historical use in past studies, they pass all three tests related to under, over and weak identification respectively, while the significance of the instruments and the overall F-test of the first stage regressions further enhance the overall validity of this specification. We report first stage regressions and the respective tests of the IV analysis in Appendix B. Second stage results are reported in specification (4) of Table 6. Seemingly, all three cultural dimensions hold their statistical significance ( $p_{\mathrm{IDV}}<0.01, p_{\mathrm{UAI}}<0.01, p_{\mathrm{PDI}}<0.1$ ), and their signs intact.

[Insert Table 6 Around Here]

\subsection{Implications of cultural overtones}

Concluding this section, a question that follows naturally regards the implications of the cultural overtones discussed up to this point. Indeed, informal institutions are crucial and bare implications worth discussing for several reasons, starting from abstract grounds on policymaking and ending on insurers' decision-making in particular. 
From a policy-making perspective, understanding the existence of cultural overtones on insurers' risk is detrimental in several ways. To begin with, if culture is a factor explaining the different perceptions of risk across countries (Weber and Hsee, 1998), it may well be the cause that we unwittingly generate risk-seeking firms exactly due to these different perceptions being fabricated into our daily actions. Thus, a better set of policies acknowledging this confounding situation and takes respective action is worth considering (Mihet, 2013). For instance, when it comes to policymakers, a set of policies promoting innovation could be introduced in not so innovative (conservative) countries, or, oppositely, a set of policies promoting conservatism in risk could be introduced in countries where the perception of risk is lower. Generally, the findings of our study provide further insight on the policy-making procedure, eventually highlighting that, when it comes to shaping global supervisory standards, one size does not fit all. In particular, for the design of more effective global supervisory standards of insurance firms, not only is important to consider formal institutional factors (such as the political environment or a country's regulatory and supervisory architecture), but also informal institutional factors (such as culture), which convey the inherent values and beliefs of locals.

Turning to the implications as to firm decision-making, the role of culture is twofold to the very least. First and on a more general note, as mentioned in Kelley et al. (1987, p.18), an essential question that cross-cultural management research aims to answer is the one posed by Adler (1983), as to what extent culture impacts upon an individual's behaviour in the workplace. This is a question that according to Laurent (1983) is crucial to consider, given that employees in multi-national settings retain their culturally-specific work behaviours in spite of common management policies and procedures. That said, culture could arguably impact firm outcomes through employees' culture-specific attributes either at the level of upper echelons or lower ranks of the organization. Second, and most related to our findings, insurance products per se are of "national character" (Hofstede, 1995) and are designed to cater the needs and beliefs of local clients. This is even more pronounced when examining international insurance companies that expand their operations in multiple regions as, in such cases, these companies need to follow a set of rules and practices that is in accordance with the local needs, values and characteristics. Therefore, a management acknowledging this situation and taking respective action is of great importance for the trajectory of the firm.

\section{Conclusion}

There is a long discussion on the forms of national culture and the influence it may exert in many respects. Over the past years, several studies document such relationships in a variety of domains that contemplate and shed light in these types of influences. Admittedly, and as have been previously argued in the literature, scholarship in finance has paid considerably less attention in contrast to other domains; yet, the number of studies considering national culture is constantly increasing. 
Prior studies link national culture to corporate risk-taking, while more recent ones provide evidence of this interplay from the viewpoint of banks. Yet, to this day, insurance firms have not been considered in this stream of research despite their intrinsic link to informal institutions. More specifically, it has been argued that insurance is a culture-specific product that is subjectively valued according to cultural patterns, while the only empirical study in this domain links insurance consumption to national culture.

In this study, we provide supporting evidence of the influence culture exerts on the risktaking of insurance firms. In a sample covering 801 firms across 42 countries over the period 2007-2016, we find a positive relationship between individualism and risk-taking and a negative relationship between uncertainty avoidance or power distance and risk-taking. We conjecture that these effects might be attributed to the insurance firms' manager or clientele's incentives, both driving the risk-taking trajectory through behavioural patterns that could be linked to national culture.

Overall, our findings relate to and reinforce two distinct strands of literature. The first concerns the determinants of insurance firms' risk, particularly the macro-level ones, the list of which is admittedly limited. The second strand of literature our paper is addressed at relates to the intersection of national culture and financial decision-making literatures, where arguably, considerably less attention has been given to. We believe that both these strands of literature require more attention, while they pose a fruitful avenue of research; particularly as to how national culture might go far in explaining voids in them. Hence, we hope that with this study we have greased the wheels for future research.

\section{Acknowledgments}

We are grateful to two anonymous reviewers and the Associate Editor, Kristina Minnick, for their remarks that greatly helped us in improving this paper. Thanks are also extended to Fotios Pasiouras and other participants of the 8th International Conference of the Financial Engineering and Banking Society for helpful comments and suggestions. All errors remain our own. 


\section{Appendices}

\section{Appendix A: Variable definitions and sources}

\begin{tabular}{|c|c|c|}
\hline Variable & Description & Source \\
\hline Z-score & Natural logarithm of $\frac{\overline{R O A}_{i}+\overline{E A}_{i}}{\sigma_{R O A i}}$ for a 3-year rolling-window period. & $\begin{array}{l}\text { Authors' elaboration } \\
\text { based on data from } \\
\text { SNL Financial }\end{array}$ \\
\hline Risk & Multiplication of the natural logarithm of 'Z-score' by minus one. & $\begin{array}{l}\text { Authors' elaboration } \\
\text { based on data from } \\
\text { SNL Financial }\end{array}$ \\
\hline LSIZE & Natural Logarithm of a firm's Total Assets. & SNL Financial \\
\hline LIST & Dummy variable, distinguishing between mutual (0) and stock insurers (1). & SNL Financial \\
\hline LIFE & $\begin{array}{l}\text { Dummy variable, distinguishing whether an insurance firm engages in } \\
\text { long-term (life) or short-term business (property/casualty) segments. }\end{array}$ & SNL Financial \\
\hline HHI & $\begin{array}{l}\text { Herfindahl-Hirschman index, } H H I_{k t}=\sum_{i=1}^{n} \text { share }_{i k t}^{2} \text {, where } \text { share }_{i k t} \\
\text { is the market share of firm } i \text { operating in country } k \text { in year } t .\end{array}$ & $\begin{array}{l}\text { Authors' elaboration on } \\
\text { SNL Financial data }\end{array}$ \\
\hline PREM & Insurance premiums (\%GDP). & $\begin{array}{l}\text { Global Financial } \\
\text { Development Database }\end{array}$ \\
\hline GDPGR & Annual GDP growth (\%). & World Bank \\
\hline INFL & Annual inflation rate $(\%)$. & World Bank \\
\hline CAP & $\begin{array}{l}\text { Stock market capitalization (CAP) is the total value of all listed shares } \\
\text { in a stock market as a percentage of GDP. }\end{array}$ & $\begin{array}{l}\text { Global Financial } \\
\text { Development Database }\end{array}$ \\
\hline VOL & $\begin{array}{l}\text { Stock price volatility (VOL) is the average of the } 360 \text {-day volatility of } \\
\text { the national stock market index. }\end{array}$ & $\begin{array}{l}\text { Global Financial } \\
\text { Development Database }\end{array}$ \\
\hline INSTDEV & $\begin{array}{l}\text { Level of Institutional Development, as proxied by a non-weighted arithmetic } \\
\text { average of the following dimensions: Voice Accountability, Political Stability, } \\
\text { Government Effectiveness, Regulatory Quality, Rule of Law and Control of Corruption. }\end{array}$ & $\begin{array}{l}\text { Worldwide Governance } \\
\text { Indicators Database }\end{array}$ \\
\hline PDI & Power Distance Index (Hierarchy). & Hofstede (2001) \\
\hline IDV & Individualism vs Collectivism. & Hofstede (2001) \\
\hline UAI & Uncertainty Avoidance Index. & Hofstede (2001) \\
\hline
\end{tabular}

\section{Appendix B: Instrumental Variables Analysis}

In the instrumental variables (IV) analysis we estimate the following two-stage model:

$$
\begin{aligned}
& \text { Culture }_{k}=\zeta+\eta_{1} \text { language }_{k}+\eta_{2} \text { religion }_{k}+\eta_{3} \text { geography }_{k}+\theta_{1} \text { Firm }_{i, k, t}+\theta_{2} \text { Country }_{k, t}+\kappa \text { Year }_{t}+r_{i, k, t} \\
& \text { Risk }_{i, k, t}=\alpha+\beta_{1} \text { Firm }_{i, k, t}+\beta_{2} \text { Country }_{k, t}+\gamma \text { Culture }_{k}+\delta \text { Year }_{t}+\varepsilon_{i, k, t}
\end{aligned}
$$

where $i$ corresponds to insurance firm $i, k$ corresponds to country $k, t$ corresponds to year $t$. Risk $_{i, k, t}$ is the inverse of 'Z-score', for firm $i$, in country $k$ in year $t$, Firm $_{i, k, t}$ denotes firm-specific attributes for insurance firm $i$ in country $k$ in year $t$, Country $y_{k, t}$ denotes country-specific attributes in country $k$ in year $t$, Culture $_{k}$ is a vector of national culture variables in country $k$, Year $_{t}$ includes year dummies in time $t, r_{i, k, t}$ and $\varepsilon_{i, k, t}$ are the residuals of the first and second stage regressions respectively. language ${ }_{k}$ is the first instrument exhibiting the percentage of population in country $k$ speaking the official language (see Alessina et al., 2003, for more details and source of original data). geography $y_{k}$ includes world region dummies taking the value of 1 if country $k$ belongs to the specified region (e.g. Europe, America, Asia, Oceania) and 0 otherwise. Information on the world regions are obtained from the World At- 


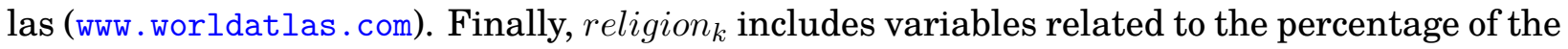
population of country $k$ aspiring to the three most spread religious faiths (e.g. Roman Catholic, Protestants, Muslim) from the study of La Porta et al. (1999). The following table reports the first and second stage results along with the weak, under and over-identification tests.

Instrumental Variables (IV) analysis results

\begin{tabular}{|c|c|c|c|}
\hline \multicolumn{4}{|l|}{ First Stage Results } \\
\hline & (1) & (2) & (3) \\
\hline & IDV & UAI & PDI \\
\hline \multirow[t]{2}{*}{ Roman Catholic } & $-0.1105^{* *}$ & $0.1942 * * *$ & 0.01467 \\
\hline & $(0.0531)$ & $(0.061)$ & $(0.0301)$ \\
\hline \multirow[t]{2}{*}{ Protestants } & 0.0181 & $-0.2391 * * *$ & $-0.1269 * * *$ \\
\hline & $(0.0511)$ & $(0.0478)$ & $(0.0355)$ \\
\hline \multirow[t]{2}{*}{ Muslim } & $0.0377^{*}$ & $0.097 * * *$ & $0.0896^{* * *}$ \\
\hline & $(0.0209)$ & $(0.033)$ & $(0.0272)$ \\
\hline \multirow{2}{*}{ Asia } & $-62.942^{* * *}$ & $15.514 * * *$ & $16.406^{* * *}$ \\
\hline & $(2.9197)$ & $(4.039)$ & $(1.6096)$ \\
\hline \multirow[t]{2}{*}{ Oceania } & $-3.3898^{* *}$ & $-3.10 *$ & 0.0872 \\
\hline & $(1.4261)$ & $(1.886)$ & $(1.603)$ \\
\hline \multirow[t]{2}{*}{ Europe } & $-26.923^{* * *}$ & $2.755^{*}$ & $4.414^{* * *}$ \\
\hline & $(0.9014)$ & $(1.562)$ & $(0.7934)$ \\
\hline \multirow[t]{2}{*}{ Language } & $9.958 * * *$ & -1.584 & 0.4751 \\
\hline & $(3.002)$ & $(3.879)$ & $(2.863)$ \\
\hline \multirow[t]{2}{*}{ Constant } & $60.408 * * *$ & $84.185^{* * *}$ & $81.448 * * *$ \\
\hline & $(5.809)$ & $(6.516)$ & $(4.070)$ \\
\hline Firm-characteristics & YES & YES & YES \\
\hline Country-characteristics & YES & YES & YES \\
\hline Year Dummies & YES & YES & YES \\
\hline F-test & $875 * * *$ & $47.60 * * *$ & $71.34 * * *$ \\
\hline \multicolumn{4}{|l|}{ Second Stage Results } \\
\hline \multirow[t]{2}{*}{ IDV } & $0.00348 * * *$ & & \\
\hline & $(0.00101)$ & & \\
\hline \multirow[t]{2}{*}{ UAI } & & $-0.00522 * * *$ & \\
\hline & & $(0.00144)$ & \\
\hline \multirow[t]{2}{*}{ PDI } & & & $-0.00397 *$ \\
\hline & & & $(0.00228)$ \\
\hline \multirow[t]{2}{*}{ Constant } & $-1.654^{* * *}$ & $-1.016^{* * *}$ & $-1.188^{* * *}$ \\
\hline & $(0.152)$ & $(0.219)$ & $(0.292)$ \\
\hline Observations & 4,375 & 4,375 & 4,375 \\
\hline Firm-characteristics & YES & YES & YES \\
\hline Country-characteristics & YES & YES & YES \\
\hline Year Dummies & YES & YES & YES \\
\hline Kleibergen-Paap rk LM statistic & $271.69 * * *$ & $145.564 * * *$ & $154.614 * * *$ \\
\hline Kleibergen-Paap Wald rk Wald F statistic & 874.85 & 47.595 & 71.342 \\
\hline Hansen J statistic (p-value) & 0.766 & 0.849 & 0.819 \\
\hline
\end{tabular}

Robust standard errors in parentheses. $* * * * *$ and $*$ indicate significance at the $1 \%, 5 \%$ and $10 \%$ levels accordingly. F-test, for the first stage, and respective under (Kleibergen-Paap rk LM statistic), weak (Kleibergen-Paap Wald rk Wald F statistic) and over-identification (Hansen $\mathrm{J}$ statistic) tests (for the second stage) are reported. All identification tests resoundingly validate the satisfaction of the necessary conditions. 


\section{References}

Adams, M. (1996). The reinsurance decision in life insurance firms: An empirical test of the risk-bearing hypothesis. Accounting \& Finance, 36(1):15-30.

Adams, M., Burton, B., and Hardwick, P. (2003). The determinants of credit ratings in the united kingdom insurance industry. Journal of Business Finance \& Accounting, 30(3-4):539_ 572.

Adler, N. J. (1983). Cross-cultural management: Issues to be faced. International Studies of Management \& Organization, 13(1-2):7-45.

Alesina, A., Devleeschauwer, A., Easterly, W., Kurlat, S., and Wacziarg, R. (2003). Fractionalization. Journal of Economic growth, 8(2):155-194.

Ashraf, B. N. and Arshad, S. (2017). Foreign bank subsidiaries' risk-taking behavior: Impact of home and host country national culture. Research in International Business and Finance, 41:318-335.

Ashraf, B. N., Zheng, C., and Arshad, S. (2016). Effects of national culture on bank risk-taking behavior. Research in International Business and Finance, 37:309-326.

Baluch, F., Mutenga, S., and Parsons, C. (2011). Insurance, systemic risk and the financial crisis. The Geneva Papers on Risk and Insurance-Issues and Practice, 36(1):126-163.

Barry, T. A., Lepetit, L., and Tarazi, A. (2011). Ownership structure and risk in publicly held and privately owned banks. Journal of Banking \& Finance, 35(5):1327-1340.

Boubakri, N., Mirzaei, A., and Samet, A. (2017). National culture and bank performance: Evidence from the recent financial crisis. Journal of Financial Stability, 29:36-56.

Boyd, J. H., De Nicoló, M. G., and Jalal, A. M. (2006). Bank Risk-Taking and Competition Revisited: New Theory and New Evidence. IMF Working Paper WP/06/297.

Boyd, J. H., Graham, S. L., and Hewitt, R. S. (1993). Bank holding company mergers with nonbank financial firms: Effects on the risk of failure. Journal of Banking \& Finance, 17(1):4363. 
Breuer, W., Riesener, M., and Salzmann, A. J. (2014). Risk aversion vs. individualism: what drives risk taking in household finance? The European Journal of Finance, 20(5):446-462.

Chen, R. and Wong, K. A. (2004). The determinants of financial health of asian insurance companies. Journal of Risk and Insurance, 71(3):469-499.

Chui, A. C. and Kwok, C. C. (2008). National culture and life insurance consumption. Journal of International Business Studies, 39(1):88-101.

Chui, A. C., Titman, S., and Wei, K. J. (2010). Individualism and momentum around the world. The Journal of Finance, 65(1):361-392.

Cummins, J. D., Harrington, S. E., and Klein, R. (1995). Insolvency experience, risk-based capital, and prompt corrective action in property-liability insurance. Journal of Banking \& Finance, 19(3):511-527.

Cummins, J. D., Rubio-Misas, M., and Vencappa, D. (2017). Competition, efficiency and soundness in european life insurance markets. Journal of Financial Stability, 28:66-78.

Das, U., Davies, N., and Podpiera, R. (2003). Insurance and Issues in Financial Soundness. IMF Working Paper No. $03 / 138$.

De Long, J. B., Shleifer, A., Summers, L. H., and Waldmann, R. J. (1989). The size and incidence of the losses from noise trading. The Journal of Finance, 44(3):681-696.

De Nicoló, M. G. and Loukoianova, E. (2007). Bank ownership, market structure and risk. IMF Working Paper WP/07/215.

Demirgüç-Kunt, A. and Detragiache, E. (1998). The determinants of banking crises in developing and developed countries. Staff Papers, 45(1):81-109.

Demirgüç-Kunt, A. and Levine, R. (1996). Stock market development and financial intermediaries: stylized facts. The World Bank Economic Review, 10(2):291-321.

Doney, P. M., Cannon, J. P., and Mullen, M. R. (1998). Understanding the influence of national culture on the development of trust. Academy of management review, 23(3):601-620. 
Doumpos, M., Gaganis, C., and Pasiouras, F. (2015). Central bank independence, financial supervision structure and bank soundness: An empirical analysis around the crisis. Journal of Banking \& Finance, 61:S69-S83.

Eling, M. and Marek, S. D. (2014). Corporate governance and risk taking: Evidence from the uk and german insurance markets. Journal of Risk and Insurance, 81(3):653-682.

Fields, L. P., Gupta, M., and Prakash, P. (2012). Risk taking and performance of public insurers: An international comparison. Journal of Risk and Insurance, 79(4):931-962.

Frijns, B., Dodd, O., and Cimerova, H. (2016). The impact of cultural diversity in corporate boards on firm performance. Journal of Corporate Finance, 41:521-541.

Gaganis, C., Liu, L., and Pasiouras, F. (2015). Regulations, profitability, and risk-adjusted returns of european insurers: An empirical investigation. Journal of Financial Stability, $18: 55-77$.

Graham, J. R., Harvey, C. R., and Puri, M. (2013). Managerial attitudes and corporate actions. Journal of Financial Economics, 109(1):103-121.

Greco, S., Ishizaka, A., Tasiou, M., and Torrisi, G. (2018). On the methodological framework of composite indices: A review of the issues of weighting, aggregation and robustness, Social Indicators Research, doi: 10.1007/s11205-017-1832-9, advance online publication.

Haiss, P. and Sümegi, K. (2008). The relationship between insurance and economic growth in europe: a theoretical and empirical analysis. Empirica, 35(4):405-431.

Harrington, S. E. (2009). The financial crisis, systemic risk, and the future of insurance regulation. Journal of Risk and Insurance, 76(4):785-819.

Hofstede, G. (1980). Culture's Consequences: International Differences in Work-Related Values. SAGE Publications, Beverly Hills, CA.

Hofstede, G. (1983). The cultural relativity of organizational practices and theories. Journal of international business studies, 14(2):75-89. 
Hofstede, G. (1984). The cultural relativity of the quality of life concept. Academy of Management review, 9(3):389-398.

Hofstede, G. (1995). Insurance as a product of national values. The Geneva Papers on Risk and Insurance Issues and Practice, 20(4):423-429.

Hofstede, G. (2001). Culture's Consequences: International Differences in Work-Related Values. 2nd edition. SAGE Publications, Beverly Hills, CA.

Hofstede, G., Hofstede, G. J., and Minkov, M. (2010). Cultures and Organizations: Software of the Mind, Third Edition. McGraw-Hill Education.

Homer, P. M. and Kahle, L. R. (1988). A structural equation test of the value-attitude-behavior hierarchy. Journal of Personality and social Psychology, 54(4):638.

Houston, J. F., Lin, C., Lin, P., and Ma, Y. (2010). Creditor rights, information sharing, and bank risk taking. Journal of Financial Economics, 96(3):485-512.

Kanagaretnam, K., Lim, C. Y., and Lobo, G. J. (2011). Effects of national culture on earnings quality of banks. Journal of International Business Studies, 42(6):853-874.

Kanagaretnam, K., Lim, C. Y., and Lobo, G. J. (2014). Influence of national culture on accounting conservatism and risk-taking in the banking industry. The Accounting Review, 89(3):1115-1149.

Karolyi, G. A. (2016). The gravity of culture for finance. Journal of Corporate Finance, 41:610625.

Kauffmann, D., Kraay, A., and Mastruzzi, M. (2010). The worldwide governance indicators: A summary of methodology, data and analytical issues. World Bank Policy Research.

Kelley, L., Whatley, A., and Worthley, R. (1987). Assessing the effects of culture on managerial attitudes: A three-culture test. Journal of International Business Studies, 18(2):17-31.

Kirkman, B. L., Lowe, K. B., and Gibson, C. B. (2006). A quarter century of culture's consequences: A review of empirical research incorporating hofstede's cultural values framework. Journal of international business studies, 37(3):285-320. 
Kreiser, P. M., Marino, L. D., Dickson, P., and Weaver, K. M. (2010). Cultural influences on entrepreneurial orientation: The impact of national culture on risk taking and proactiveness in SMEs. Entrepreneurship: Theory and Practice, 34(5):959-983.

Kwok, C. C. and Tadesse, S. (2006). National culture and financial systems. Journal of International business studies, 37(2):227-247.

La Porta, R., Lopez-de Silanes, F., Shleifer, A., and Vishny, R. (1999). The quality of government. The Journal of Law, Economics, and Organization, 15(1):222-279.

Laeven, L. and Levine, R. (2009). Bank governance, regulation and risk taking. Journal of financial economics, 93(2):259-275.

Laurent, A. (1983). The cultural diversity of western conceptions of management. International Studies of Management \& Organization, 13(1-2):75-96.

Lepetit, L., Nys, E., Rous, P., and Tarazi, A. (2008). Bank income structure and risk: An empirical analysis of european banks. Journal of Banking \& Finance, 32(8):1452-1467.

Li, K., Griffin, D., Yue, H., and Zhao, L. (2013). How does culture influence corporate risktaking? Journal of Corporate Finance, 23:1-22.

Low, A. (2009). Managerial risk-taking behavior and equity-based compensation. Journal of Financial Economics, 92(3):470-490.

Mihet, R. (2013). Effects of culture on firm risk-taking: a cross-country and cross-industry analysis. Journal of Cultural Economics, 37(1):109-151.

Milidonis, A., Nishikawa, T., and Shim, J. (2017). Ceo inside debt and risk taking: Evidence from property-liability insurance firms. Journal of Risk and Insurance.

Milidonis, A. and Stathopoulos, K. (2011). Do us insurance firms offer the âĂIJwrongâĂ incentives to their executives? Journal of Risk and Insurance, 78(3):643-672.

Mourouzidou-Damtsa, S., Milidonis, A., and Stathopoulos, K. (2017). National culture and bank risk-taking doi: 10.1016/j.jfs.2017.08.007, advance online publication. Journal of Financial Stability. 
OECD (2017). OECD Insurance Statistics 2016. OECD Publishing, Paris.

Pasiouras, F. and Gaganis, C. (2013). Regulations and soundness of insurance firms: International evidence. Journal of Business Research, 66(5):632-642.

Petersen, M. A. (2009). Estimating standard errors in finance panel data sets: Comparing approaches. The Review of Financial Studies, 22(1):435-480.

PricewaterhouseCoopers (2008). Reward: A new paradigm? www.pwc.com/gx/en/bankingcapital-markets/pdf/reward.pdf, accessed: 1/15/2018.

Rajgopal, S. and Shevlin, T. (2002). Empirical evidence on the relation between stock option compensation and risk taking. Journal of Accounting and Economics, 33(2):145-171.

Schaeck, K., Cihak, M., Maechler, A., and Stolz, S. (2011). Who disciplines bank managers? Review of Finance, 16(1):197-243.

Shane, S. (1993). Cultural influences on national rates of innovation. Journal of Business Venturing, 8(1):59-73.

Shao, L., Kwok, C. C., and Zhang, R. (2013). National culture and corporate investment. Journal of International Business Studies, 44(7):745-763.

Shavell, S. (1979). On moral hazard and insurance. In Foundations of Insurance Economics, pages 280-301. Springer.

Shim, J. (2011). Mergers \& acquisitions, diversification and performance in the us propertyliability insurance industry. Journal of Financial Services Research, 39(3):119-144.

Shim, J. (2017). An investigation of market concentration and financial stability in propertyliability insurance industry. Journal of risk and insurance, 84(2):567-597.

Stiglitz, J. E. (1983). Risk, incentives and insurance: The pure theory of moral hazard. Geneva Papers on Risk and Insurance, pages 4-33.

Tarashev, N., Borio, C., and Tsatsaronis, K. (2009). The systemic importance of financial institutions. BIS Quarterly Review, 449(September):75-87. 
Van den Steen, E. (2004). Rational overoptimism (and other biases). The American Economic Review, 94(4):1141-1151.

Weber, E. U. and Hsee, C. (1998). Cross-cultural differences in risk perception, but crosscultural similarities in attitudes towards perceived risk. Management science, 44(9):12051217.

Williamson, O. E. (2000). The new institutional economics: taking stock, looking ahead. Journal of economic literature, 38(3):595-613. 


\section{Tables}

Table 1: Summary statistics.

\begin{tabular}{|c|c|c|c|}
\hline Variable & Obs. & Mean & Std. \\
\hline \multicolumn{4}{|c|}{ Panel A: firm-level variables } \\
\hline Risk & 6271 & -1.379 & 0.536 \\
\hline LIFE & 6271 & 0.457 & 0.498 \\
\hline SIZE & 6271 & 7.063 & 0.902 \\
\hline STOCK & 6271 & 0.358 & 0.480 \\
\hline \multicolumn{4}{|c|}{ Panel B: country-level variables } \\
\hline GDPGR & 6271 & 2.021 & 2.891 \\
\hline INFL & 6271 & 2.072 & 2.121 \\
\hline $\mathrm{HHI}$ & 6271 & 0.151 & 0.149 \\
\hline PREM & 5428 & 4.012 & 2.325 \\
\hline INSTDEV & 6235 & 1.098 & 0.629 \\
\hline CAP & 5027 & 90.400 & 78.971 \\
\hline VOL & 5464 & 20.214 & 7.772 \\
\hline PDI & 6271 & 49.012 & 19.859 \\
\hline IDV & 6271 & 64.730 & 24.060 \\
\hline UAI & 6271 & 57.352 & 21.381 \\
\hline
\end{tabular}

Note: Variables are defined in Appendix A. 


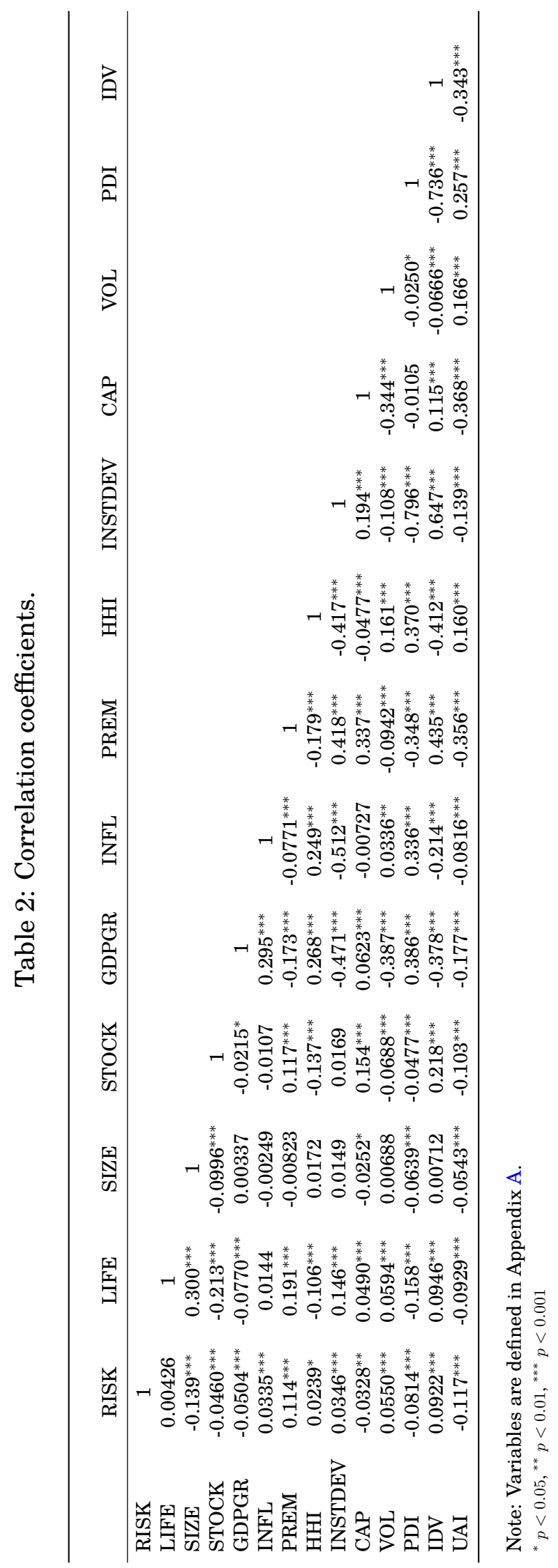


Table 3: National culture and insurers' risk - The effect of individualism.

\begin{tabular}{|c|c|c|c|c|c|c|}
\hline VARIABLES & $\begin{array}{c}(1) \\
\text { Baseline }\end{array}$ & $\begin{array}{c}(2) \\
\text { Macro }\end{array}$ & $\begin{array}{c}(3) \\
\text { Insurance }\end{array}$ & $\begin{array}{c}(4) \\
\text { Institutions }\end{array}$ & $\begin{array}{c}(5) \\
\text { Stock Market }\end{array}$ & $\begin{array}{l}(6) \\
\text { All }\end{array}$ \\
\hline IDV & $\begin{array}{l}0.00102^{* *} \\
(0.000495)\end{array}$ & $\begin{array}{l}0.00152 * * * \\
(0.000563)\end{array}$ & $\begin{array}{l}0.00132 * * \\
(0.000540)\end{array}$ & $\begin{array}{l}0.00213 * * * \\
(0.000673)\end{array}$ & $\begin{array}{l}0.00113^{*} \\
(0.000594)\end{array}$ & $\begin{array}{l}0.00227 * * * \\
(0.000792)\end{array}$ \\
\hline SIZE & $\begin{array}{l}-0.0411^{* *} \\
(0.0188)\end{array}$ & $\begin{array}{l}-0.0450 * * \\
(0.0187)\end{array}$ & $\begin{array}{l}-0.0311^{*} \\
(0.0186)\end{array}$ & $\begin{array}{l}-0.0461^{* *} \\
(0.0189)\end{array}$ & $\begin{array}{l}-0.0151 \\
(0.0192)\end{array}$ & $\begin{array}{l}-0.0268 \\
(0.0193)\end{array}$ \\
\hline STOCK & $\begin{array}{l}-0.0527 * * \\
(0.0267)\end{array}$ & $\begin{array}{l}-0.0534 * * \\
(0.0265)\end{array}$ & $\begin{array}{l}-0.0438 \\
(0.0278)\end{array}$ & $\begin{array}{l}-0.0586^{* *} \\
(0.0265)\end{array}$ & $\begin{array}{l}-0.0485 \\
(0.0300)\end{array}$ & $\begin{array}{l}-0.0404 \\
(0.0298)\end{array}$ \\
\hline LIFE & $\begin{array}{l}0.0199 \\
(0.0287)\end{array}$ & $\begin{array}{l}0.0231 \\
(0.0285)\end{array}$ & $\begin{array}{l}0.0218 \\
(0.0296)\end{array}$ & $\begin{array}{l}0.0274 \\
(0.0289)\end{array}$ & $\begin{array}{l}0.0200 \\
(0.0314)\end{array}$ & $\begin{array}{l}0.0281 \\
(0.0310)\end{array}$ \\
\hline GDPGR & & $\begin{array}{l}0.00434 \\
(0.00458)\end{array}$ & & & & $\begin{array}{l}0.00240 \\
(0.00616)\end{array}$ \\
\hline INFL & & $\begin{array}{l}0.0122^{*} \\
(0.00658)\end{array}$ & & & & $\begin{array}{l}0.0143^{*} \\
(0.00745)\end{array}$ \\
\hline PREM & & & $\begin{array}{l}0.00165 \\
(0.00608)\end{array}$ & & & $\begin{array}{l}0.0126 \\
(0.00784)\end{array}$ \\
\hline $\mathrm{HHI}$ & & & $\begin{array}{l}0.251^{* *} \\
(0.102)\end{array}$ & & & $\begin{array}{l}0.235^{* *} \\
(0.110)\end{array}$ \\
\hline INSTDEV & & & & $\begin{array}{l}-0.0668^{* *} \\
(0.0260)\end{array}$ & & $\begin{array}{l}-0.0371 \\
(0.0376)\end{array}$ \\
\hline CAP & & & & & $\begin{array}{l}-0.000447 \\
(0.000332)\end{array}$ & $\begin{array}{l}-0.000368 \\
(0.000344)\end{array}$ \\
\hline VOL & & & & & $\begin{array}{l}0.00277 \\
(0.00279)\end{array}$ & $\begin{array}{l}0.00215 \\
(0.00287)\end{array}$ \\
\hline Constant & $\begin{array}{l}-1.363^{* * *} \\
(0.134)\end{array}$ & $\begin{array}{l}-1.421^{* * * *} \\
(0.133)\end{array}$ & $\begin{array}{l}-1.523^{* * *} \\
(0.134)\end{array}$ & $\begin{array}{l}-1.327 * * * \\
(0.136)\end{array}$ & $\begin{array}{l}-1.546^{* * * *} \\
(0.152)\end{array}$ & $\begin{array}{l}-1.667^{* * * *} \\
(0.156)\end{array}$ \\
\hline Observations & 6,271 & 6,271 & 5,428 & 6,235 & 4,882 & 4,837 \\
\hline Year Dummies & YES & YES & YES & YES & YES & YES \\
\hline Insurance firms & 801 & 801 & 794 & 800 & 755 & 755 \\
\hline Countries & 42 & 42 & 42 & 41 & 38 & 38 \\
\hline
\end{tabular}

For the sake of transparency, in estimating the relationship between national culture and insurance firm risk we use variations of eq.(2) as reported in columns (1) to (5). More specifically, column (1) represents the baseline model, considering only firm-specific attributes. In columns (2) to (5) we extend the baseline model by controlling for each set of country-level variables (e.g. macro, insurance, institutional or stock-market related), as discussed in Subsection 3.1.3. Column (6) reports results for the overall model, as discussed in Section 3.2 and written in eq.(2), which essentially embeds all previous variations. All specifications of the model are estimated using random effects generalized least squares (GLS), the validity of which against their OLS variants are verified by the Breusch and Pagan LM test (unreported). Nonetheless, we found no significant differences in using OLS. All regressions are estimated with robust standard errors clustered by insurance firm, which are reported in parentheses. ***, **, and * indicate significance at the $1 \%, 5 \%$ and $10 \%$ levels, respectively. Variables are defined in Appendix A. 
Table 4: National culture and insurers' risk - The effect of uncertainty avoidance.

\begin{tabular}{|c|c|c|c|c|c|c|}
\hline \multirow[b]{2}{*}{ VARIABLES } & (1) & (2) & (3) & (4) & (5) & (6) \\
\hline & Baseline & Macro & Insurance & Institutions & Stock Market & Overall \\
\hline \multirow[t]{2}{*}{ UAI } & $-0.00259 * * *$ & $-0.00249 * * *$ & $-0.00274 * * *$ & $-0.00268^{* * *}$ & $-0.00412^{* * *}$ & $-0.00424^{* * *}$ \\
\hline & $(0.000615)$ & $(0.000621)$ & $(0.000643)$ & $(0.000618)$ & $(0.000756)$ & $(0.000811)$ \\
\hline \multirow[t]{2}{*}{ SIZE } & $-0.0481^{* *}$ & $-0.0494 * * *$ & $-0.0381^{* *}$ & $-0.0497 * * *$ & -0.0311 & $-0.0381^{*}$ \\
\hline & $(0.0189)$ & $(0.0189)$ & $(0.0188)$ & $(0.0190)$ & $(0.0195)$ & $(0.0197)$ \\
\hline \multirow[t]{2}{*}{ STOCK } & $-0.0483^{*}$ & $-0.0460 *$ & -0.0375 & $-0.0466^{*}$ & -0.0382 & -0.0188 \\
\hline & $(0.0264)$ & $(0.0263)$ & $(0.0279)$ & $(0.0264)$ & $(0.0294)$ & $(0.0299)$ \\
\hline \multirow[t]{2}{*}{ LIFE } & 0.0152 & 0.0188 & 0.0169 & 0.0186 & 0.0170 & 0.0222 \\
\hline & $(0.0289)$ & $(0.0290)$ & $(0.0299)$ & $(0.0292)$ & $(0.0317)$ & $(0.0312)$ \\
\hline \multirow[t]{2}{*}{ GDPGR } & & 0.000765 & & & & -0.00237 \\
\hline & & $(0.00450)$ & & & & $(0.00632)$ \\
\hline \multirow[t]{2}{*}{ INFL } & & 0.00828 & & & & 0.0107 \\
\hline & & $(0.00635)$ & & & & $(0.00761)$ \\
\hline \multirow[t]{2}{*}{ PREM } & & & 0.00252 & & & 0.0115 \\
\hline & & & $(0.00603)$ & & & $(0.00784)$ \\
\hline \multirow[t]{2}{*}{$\mathrm{HHI}$} & & & $0.248 * *$ & & & $0.292^{* *}$ \\
\hline & & & $(0.102)$ & & & $(0.115)$ \\
\hline \multirow[t]{2}{*}{ INSTDEV } & & & & -0.0268 & & 0.0113 \\
\hline & & & & $(0.0199)$ & & $(0.0334)$ \\
\hline CAP & & & & & $\begin{array}{l}-0.00104 * * * \\
(0.000335)\end{array}$ & $\begin{array}{l}-0.00106 * * * \\
(0.000351)\end{array}$ \\
\hline VOL & & & & & $\begin{array}{l}0.00409 \\
(0.00286)\end{array}$ & $\begin{array}{l}0.00336 \\
(0.00293)\end{array}$ \\
\hline Constant & $\begin{array}{l}-1.101^{* * *} \\
(0.144)\end{array}$ & $\begin{array}{l}-1.128^{* * * *} \\
(0.143)\end{array}$ & $\begin{array}{l}-1.237 * * * \\
(0.142)\end{array}$ & $\begin{array}{l}-1.058^{* * * *} \\
(0.150)\end{array}$ & $\begin{array}{l}-1.084^{* * *} \\
(0.167)\end{array}$ & $\begin{array}{l}-1.181^{* * *} \\
(0.179)\end{array}$ \\
\hline Observations & 6,271 & 6,271 & 5,428 & 6,235 & 4,882 & 4,837 \\
\hline Year Dummies & YES & YES & YES & YES & YES & YES \\
\hline Insurance firms & 801 & 801 & 794 & 800 & 755 & 755 \\
\hline Countries & 42 & 42 & 42 & 41 & 38 & 38 \\
\hline
\end{tabular}

For the sake of transparency, in estimating the relationship between national culture and insurance firm risk we use variations of eq.(2) as reported in columns (1) to (5). More specifically, column (1) represents the baseline model, considering only firm-specific attributes. In columns (2) to (5) we extend the baseline model by controlling for each set of country-level variables (e.g. macro, insurance, institutional or stock-market related), as discussed in Subsection 3.1.3. Column (6) reports results for the overall model, as discussed in Section 3.2 and written in eq.(2), which essentially embeds all previous variations. All specifications of the model are estimated using random effects generalized least squares (GLS), the validity of which against their OLS variants are verified by the Breusch and Pagan LM test (unreported). Nonetheless, we found no significant differences in using OLS. All regressions are estimated with robust standard errors clustered by insurance firm, which are reported in parentheses. ${ }^{* *},{ }^{* *}$, and $*$ indicate significance at the $1 \%, 5 \%$ and $10 \%$ levels, respectively. Variables are defined in Appendix A. 
Table 5: National culture and insurers' risk - The effect of power distance.

\begin{tabular}{|c|c|c|c|c|c|c|}
\hline & (1) & $(2)$ & (3) & (4) & (5) & (6) \\
\hline VARIABLES & Baseline & Macro & Insurance & Institutions & Stock Market & Overall \\
\hline PDI & $\begin{array}{l}-0.00130 * * \\
(0.000633)\end{array}$ & $\begin{array}{l}-0.00217 * * * \\
(0.000753)\end{array}$ & $\begin{array}{l}-0.00173^{* *} \\
(0.000694)\end{array}$ & $\begin{array}{l}-0.00392 * * * \\
(0.000952)\end{array}$ & $\begin{array}{l}-0.00107 \\
(0.000676)\end{array}$ & $\begin{array}{l}-0.00375^{* * *} \\
(0.00105)\end{array}$ \\
\hline SIZE & $\begin{array}{l}-0.0412^{* *} \\
(0.0189)\end{array}$ & $\begin{array}{l}-0.0458^{* *} \\
(0.0188)\end{array}$ & $\begin{array}{l}-0.0311^{*} \\
(0.0187)\end{array}$ & $\begin{array}{l}-0.0494^{* * *} \\
(0.0191)\end{array}$ & $\begin{array}{l}-0.0140 \\
(0.0193)\end{array}$ & $\begin{array}{l}-0.0281 \\
(0.0195)\end{array}$ \\
\hline STOCK & $\begin{array}{l}-0.0485^{*} \\
(0.0264)\end{array}$ & $\begin{array}{l}-0.0474^{*} \\
(0.0261)\end{array}$ & $\begin{array}{l}-0.0383 \\
(0.0277)\end{array}$ & $\begin{array}{l}-0.0525^{* *} \\
(0.0261)\end{array}$ & $\begin{array}{l}-0.0419 \\
(0.0298)\end{array}$ & $\begin{array}{l}-0.0326 \\
(0.0298)\end{array}$ \\
\hline LIFE & $\begin{array}{l}0.0166 \\
(0.0289)\end{array}$ & $\begin{array}{l}0.0175 \\
(0.0286)\end{array}$ & $\begin{array}{l}0.0178 \\
(0.0296)\end{array}$ & $\begin{array}{l}0.0220 \\
(0.0288)\end{array}$ & $\begin{array}{l}0.0189 \\
(0.0317)\end{array}$ & $\begin{array}{l}0.0227 \\
(0.0311)\end{array}$ \\
\hline GDPGR & & $\begin{array}{l}0.00478 \\
(0.00464)\end{array}$ & & & & $\begin{array}{l}0.00110 \\
(0.00612)\end{array}$ \\
\hline INFL & & $\begin{array}{l}0.0140^{* *} \\
(0.00686)\end{array}$ & & & & $\begin{array}{l}0.0142^{*} \\
(0.00744)\end{array}$ \\
\hline PREM & & & $\begin{array}{l}0.00113 \\
(0.00623)\end{array}$ & & & $\begin{array}{l}0.0154^{* *} \\
(0.00784)\end{array}$ \\
\hline HHI & & & $\begin{array}{l}0.255^{* *} \\
(0.103)\end{array}$ & & & $\begin{array}{l}0.233^{* *} \\
(0.111)\end{array}$ \\
\hline INSTDEV & & & & $\begin{array}{l}-0.107 * * * \\
(0.0299)\end{array}$ & & $\begin{array}{l}-0.0857 * * \\
(0.0431)\end{array}$ \\
\hline CAP & & & & & $\begin{array}{l}-0.000380 \\
(0.000320)\end{array}$ & $\begin{array}{l}-0.000129 \\
(0.000352)\end{array}$ \\
\hline VOL & & & & & $\begin{array}{l}0.00264 \\
(0.00279)\end{array}$ & $\begin{array}{l}0.00144 \\
(0.00287)\end{array}$ \\
\hline Constant & $\begin{array}{l}-1.233^{* * *} \\
(0.141)\end{array}$ & $\begin{array}{l}-1.218^{* * *} \\
(0.139)\end{array}$ & $\begin{array}{l}-1.351^{* * *} \\
(0.142)\end{array}$ & $\begin{array}{l}-0.929 * * * \\
(0.172)\end{array}$ & $\begin{array}{l}-1.434^{* * *} \\
(0.158)\end{array}$ & $\begin{array}{l}-1.294^{* * *} \\
(0.186)\end{array}$ \\
\hline Observations & 6,271 & 6,271 & 5,428 & 6,235 & 4,882 & 4,837 \\
\hline Year Dummies & YES & YES & YES & YES & YES & YES \\
\hline Insurance firms & 801 & 801 & 794 & 800 & 755 & 755 \\
\hline Countries & 42 & 42 & 42 & 41 & 38 & 38 \\
\hline
\end{tabular}

For the sake of transparency, in estimating the relationship between national culture and insurance firm risk we use variations of eq.(2) as reported in columns (1) to (5). More specifically, column (1) represents the baseline model, considering only firm-specific attributes. In columns (2) to (5) we extend the baseline model by controlling for each set of country-level variables (e.g. macro, insurance, institutional or stock-market related), as discussed in Subsection 3.1.3. Column (6) reports results for the overall model, as discussed in Section 3.2 and written in eq.(2), which essentially embeds all previous variations. All specifications of the model are estimated using random effects generalized least squares (GLS), the validity of which against their OLS variants are verified by the Breusch and Pagan LM test (unreported). Nonetheless, we found no significant differences in using OLS. All regressions are estimated with robust standard errors clustered by insurance firm, which are reported in parentheses. $* * *, * *$, and $*$ indicate significance at the $1 \%, 5 \%$ and $10 \%$ levels, respectively. Variables are defined in Appendix A. 


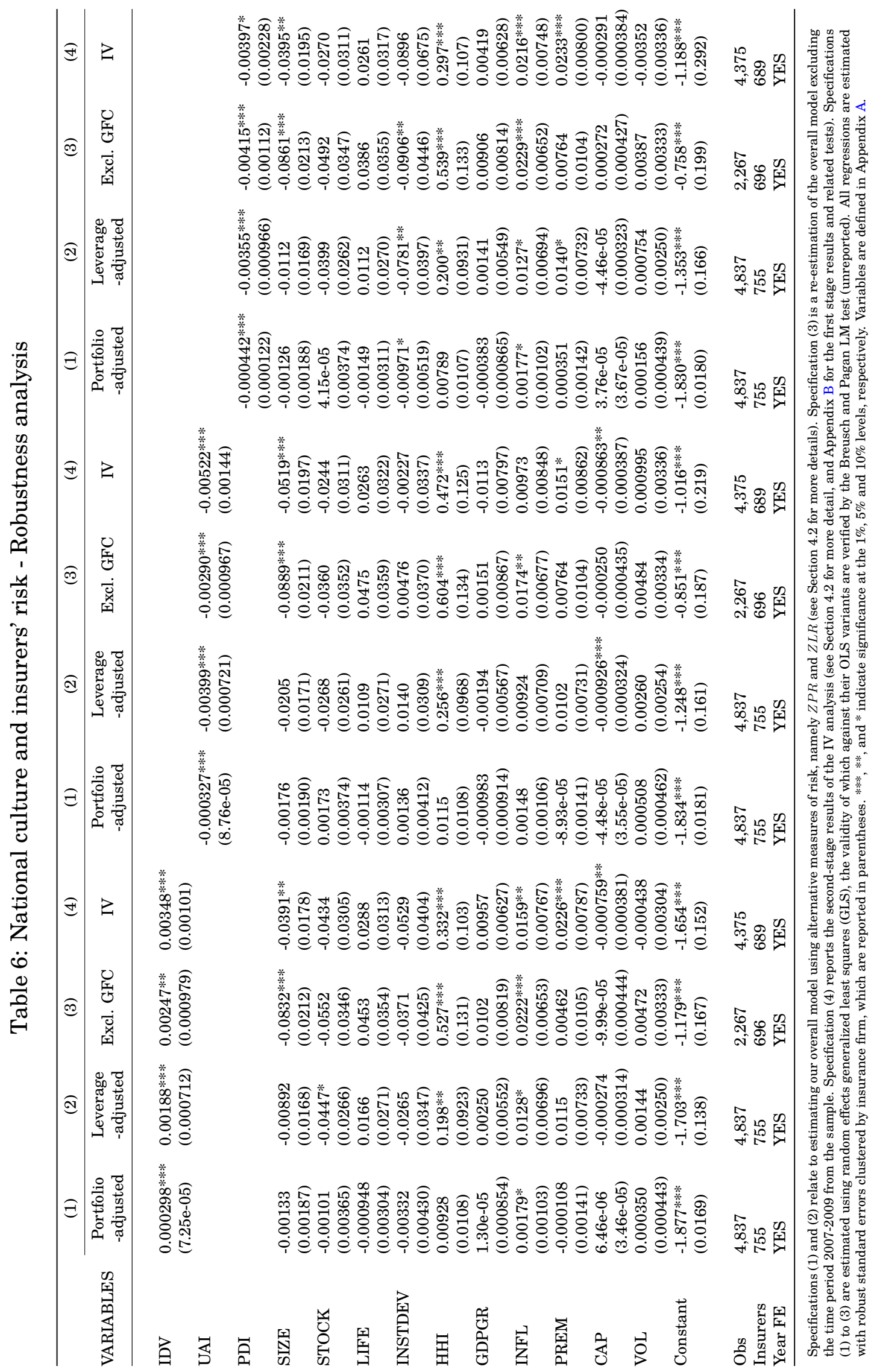

